\title{
Pengaruh Layanan Konseling Kelompok Pendekatan Realitas Terhadap Kemandirian Belajar Siswa
}

\author{
Novi Wahyu Sucianti ${ }^{1}$ \\ ${ }^{1}$ Bimbingan dan Konseling, Universitas Negeri Medan \\ noviwahyusucianti@gmail.com
}

$\begin{array}{ccc}\text { First received: } & \text { Revised: } & \text { Final Accepted: } \\ \text { 01 November } 2020 & \text { 07 November } 2020 & \text { 04 Desember 2020 }\end{array}$

\begin{abstract}
This study aims to determine the effect of the reality approach group counseling service on the learning independence of grade VII students at MTsN 2 Medan. The formulation of the problem in this study is: Is There an Effect of Reality Approach Group Counseling Services on Learning Independence of Class VII Students at MTsN 2 Medan in the 2018/2019 Academic Year. The method used in this research is quantitative method. This type of research is Quasi experimental with the type of Pre test-post test one group design. The subjects in this study were 8 students of class VII9 who had a low level of learning independence. Instruments were given before and after the implementation of group counseling. Data were analyzed using the Wilcoxon test to see whether there was a significant effect of group counseling on the reality approach on student learning independence. This can be obtained from the calculation results with the initial test score (pre-test) in the experimental group obtained an average $=85$ while the post-test data obtained an average $=128.87$. This can be obtained from the Wilcoxon test which shows that the Wilcoxon level test obtained Jcount $=16$ while Jtable $=4$. From the critical value table $\mathrm{J}$ for the Wilcoxon level test for $n=8, \alpha=0.05$ in accordance with the criteria for acceptance and rejection of the hypothesis, the hypothesis is accepted if Jcount $>$ Jtabel is Jhitung $>$ Jtabel where 16>4, from this calculation it can be seen treatment in the experimental group means that the hypothesis that says there is a significant effect of giving reality approach group counseling on the learning independence of class VII students of MTsN 2 Medan in the 2018/2019 academic year can be accepted.
\end{abstract}

Keywords: Group Counseling, Reallity Approach, Learning Independence

\begin{abstract}
Abstrak
Penelitian ini bertujuan untuk mengetahui pengaruh layanan konseling kelompok pendekatan realitas terhadap kemandirian belajar siswa kelas VII di MTsN 2 Medan. Rumusan masalah dalam penelitian ini adalah: Apakah Ada Pengaruh Layanan Konseling Kelompok Pendekatan Realitas Terhadap Kemandirian Belajar Siswa Kelas VII di MTsN 2 Medan Tahun Ajaran 2018/2019. Metode yang digunakan dalam penelitian ini adalah metode kuantitatif. Jenis penelitian ini adalah Quasi experimental dengan jenis Pre test-post test one group design. Subjek dalam penelitian ini adalah 8 orang siswa kelas VII-9 yang tingkat kemandirian belajarnya rendah. Instrumen yang digunakan adalah skala kemandirian belajar. Instrumen diberikan sebelum dan sesudah pelaksanaan konseling kelompok. Data dianalisis menggunakan uji Wilcoxon untuk melihat adakah pengaruh signifikan pemberian konseling kelompok pendekatan realitas terhadap kemandirian belajar siswa. Hal ini dapat diperoleh hasil perhitungan
\end{abstract}


dengan skor tes awal (pre-test) pada kelompok eksperimen diperoleh rata-rata $=85$ sedangkan data post-test diperoleh rata-rata $=128,87$. Hal ini dapat diperoleh dari uji Wilcoxon yang menunjukkan bahwa uji jenjang Wilcoxon diperoleh Jhitung $=16$ sedangkan Jtabel $=4$. Dari tabel nilai kritis $J$ untuk uji jenjang bertanda Wilcoxon untuk $n=8, \alpha=0,05$ sesuai dengan kriteria dengan penerimaan dan penolakan hipotesis, hipotesis diterima jika Jhitung > Jtabel yaitu Jhitung > Jtabel di mana $16>4$, dari perhitungan ini dapat dilihat perlakuan pada kelompok eksperimen artinya hipotesis yang berbunyi ada pengaruh signifikan pemberian konseling kelompok pendekatan realitas terhadap kemandirian belajar siswa kelas VII MTsN 2 Medan tahun ajaran 2018/2019 dapat diterima.

Kata Kunci: Konseling Kelompok, Pendekatan Realitas, Kemandirian Belajar

\section{PENDAHULUAN}

Pencapaian tujuan belajar berarti akan menghasilkan hasil belajar, hasil belajar dinyatakan sebagai tingkat keberhasilan belajar yang dinyatakan dalam bentuk skor, setelah melakukan proses belajar. Keberhasilan belajar menjadi dambaan setiap siswa, untuk mencapai keberhasilan belajar juga tidak mudah, banyak faktor yang mempengaruhi hasil belajar siswa antara lain faktor internal dan faktor eksternal.

Faktor internal adalah faktor yang ditimbulkan dari dalam diri individu terutama minat dan motivasi yang akan mendorong siswa untuk bersikap mandiri dalam belajar, sedangkan faktor eksternal adalah faktor yang ditimbulkan dari kondisi yang berkembang di luar kehidupan pribadi anak. Adapun faktor internal meliputi: (1) faktor fisiologi misalnya mengalami sakit, cacat tubuh atau perkembangan yang tidak sempurna, dan (2) faktor psikologis misalnya intelegensi, motivasi, persepsi, sikap, bakat, kemandirian, dan lain-lain. Sedangkan faktor yang berasal dari luar diri siswa, seperti kurikulum, kompetensi profesionalisme guru, fasilitas belajar, lingkungan sekolah, lingkungan keluarga, lingkungan belajar. Slameto (2010: 54-60).

Kemandirian dalam belajar di artikan sebagai aktivitas belajar yang di dorong oleh kemauan sendiri, pilihan sendiri dan tanggung jawab sendiri dari pembelajaran (Tirtaraharja, 2005: 50). Dengan demikian, siswa mengatur kegiatan belajar sendiri dengan mengaktifkan kognitif, afektif dan perilaku yang ada pada dirinya sehingga tercapai tujuan belajar yang diinginkan.

Fenomena di lapangan menunjukan bahwa masih terdapat siswa yang memiliki tingkat kemandirian belajar yang rendah, meskipun terdapat pula siswa yang sudah berhasil mencapai kemandirian belajar yang sesuai dalam perkembangannya. Dari hasil penelitian pada data AUM PTSDL pada siswa kelas VII-9 di MTsN 2 Medan Tahun Ajaran 2018/2019 menunjukkan masalah pada bidang keterampilan belajar (57,5\%), Prasyarat Penguasaan Materi Pelajaran (4,9\%), Sarana Belajar $(5,6 \%)$, Keadaan. Diri Sendiri (19,1\%), Keadaan Lingkungan Fisik dan Lingkungan SosioEmosional (12,7\%). Dapat dilihat bahwa siswa banyak merasakan masalah pada bidang keterampilan belajar $(57,5 \%)$. Salah satu aspek keterampilan belajar yang rendah adalah kemandirian siswa dalam belajar. Sebagaimana yang dikatakan oleh Lilik dkk (2013: 64) bahwa kemandirian belajar adalah suatu keterampilan belajar yang dalam proses belajar individu didorong, dikendalikan, dan dinilai oleh diri individu itu sendiri. 
Selaras dengan hasil wawancara pada guru Bimbingan dan Konseling yang juga mengatakan bahwa di kelas VII-9 terdapat anak yang mengalami kemandirian belajar rendah seperti tidak memiliki inisiatif belajar, tidak percaya diri dalam belajar, tidak bertanggung jawab, yang ditandai dengan seringnya siswa keluar kelas ketika guru tidak berada dalam kelas, siswa lebih memilih ngobrol dengan teman sebangku daripada belajar sendiri sehingga kondisi kelas cenderung tidak kondusif dan ribut.

Perilaku tersebut menggambarkan rendahnya kemandirian belajar siswa, perilaku ini sangat meresahkan dan jauh dari karakter bangsa. Siswa merasa terbiasa dengan hal yang tidak baik, sehingga merasa aneh jika harus mengerjakan semuanya sendiri, mencontek mereka sebut dengan budaya saling membantu sesama teman dan menomor satukan kebersamaan. Mungkin maksudnya baik namun caranya yang salah, karena mereka tidak memperdulikan apa yang sebenarnya harus ditanamkan dalam diri, sebuah kejujuran, kemandirian dan tanggung jawab. Padahal proses pembelajaran seyogyanya didesain agar peserta didik dapat secara aktif mengembangkan segenap potensi yang dimilikinya, dengan mengedepankan pembelajaran yang berpusat pada siswa (student centered) sedangkan peran guru hanya sebagai fasilitator belajar.

Bernard \& Fullmer dalam Prayitno dan Erman Amti (2004:99) mengemukakan bahwa bimbingan merupakan proses pemberian bantuan yang dilakukan oleh orang yang ahli kepada seorang atau beberapa orang individu, baik anak- anak, remaja, maupun dewasa, agar orang yang dibimbing dapat mengembangkan kemampuan dirinya sendiri dan mandiri; dengan memanfaatkan kekuatan individu dan sarana yang ada dan dapat dikembangkan berdasarkan norma- norma yang berlaku. Sedangkan Prayitno (2004:105) menyatakan bahwa konseling merupakan proses pemberian bantuan yang dilakukan melalui wawancara konseling oleh seorang ahli kepada individu yang sedang mengalami sesuatu masalah yang bermuara pada teratasinya masalah yang dihadapi oleh klien. Jadi, bimbingan dan konseling adalah suatu proses dalam usaha membantu klien dalam mengentaskan masalah yang dialami oleh klien dan mengembangkan dirinya menjadi pribadi yang mandiri. Dan pelaksana dari kegiatan bimbingan dan konseling ini disebut konselor atau guru pembimbing Pelaksanaan layanan bimbingan konseling perlu dilakukan mengingat masih belum efektifnya layanan- layanan tersebut di sekolah.

Untuk itu salah satu layanan Bimbingan dan Konseling yang dirasa dapat mengoptimalkan kemandirian siswa adalah layanan konseling kelompok. Pelaksanaan konseling kelompok yang cocok untuk mengatasi masalah kemandirian belajar siswa yang rendah adalah dengan pendekatan realitas. Glasser dalam Kurnanto (2014:79) mengatakan bahwa tanggung jawab merupakan inti dari teori Realitas. Terapi bertumpu pada ide yang berpusat pada anggota kelompok yang bebas memilih perilaku dan harus bertanggung jawab tidak hanya atas apa yang kelompok lakukan, tetapi juga bagaimana anggota kelompok berfikir dan merasakan.

\section{KAJIAN TEORITIS}

Menurut Kamus Besar Bahasa Indonesia kemandirian adalah keadaan dapat berdiri sendiri tanpa bergantung pada orang lain. Kemandirian meliputi "prilaku mampu berinisiatif, mampu 
mengatasi melakukan sesuatu sendiri tanpa bantuan orang lain" Imam Barnadib (Fatimah, 2006: 142). Pendapat tersebut juga diperkuat oleh pernyataan Kartini dan Dali (Fatimah, 2006: 142) yang menyatakan bahwa kemandirian adalah "Hasrat untuk mengerjakan segala sesuatu bagi diri sendiri".

Menurut Moore dalam Rusman (2017:365) kemandirian belajar peserta didik adalah sejauh mana dalam proses pembelajaran itu siswa dapat ikut menentukan tujuan, bahan dari pengalaman belajar, serta evaluasi pembelajarannya. Sejalan dengan pendapat Brookfield dalam Yamin (2017: 107) yang menyatakan bahwa belajar mandiri adalah belajar yang dilakukan oleh peserta didik secara bebas menentukan tujuan belajarnya, arah belajarnya, menggunakan sumber-sumber belajar yang dipilihnya, membuat keputusan akademik, dan melakukan kegiatan-kegiatan untuk tercapainya tujuan belajarnya.

Terapi Realitas dikembangkan pada tahun 1960-an oleh seorang psikiater sekaligus insinyur kimia terkemuka, William Glasser. Ia mengembangkan terapi realitas untuk membuktikan bahwa psikiatri konvensional yang selama ini ada, sebagian besar telah berlandaskan asumsiasumsi yang keliru. Bahkan Glasser juga menolak pandangan Sigmund Freud mengenai aliran psikoanalisisnya yang berdasarkan alam bawah sadar manusia, karena teorinya diangap kurang jelas.

Sejak kemunculannya, terapi realitas telah mengalami berbagai perkembangan yang sangat pesat dan telah digunakan oleh banyak konselor. Ini semua tak lepas dari konsep yang ditawarkan oleh William Glasser yang sangat sederhana dan mudah dipraktikkan. Ciri yang khas dari pendekatan ini adalah tidak terpaku pada kejadian-kejadian di masa lalu, tetapi lebih mendorong konseli untuk menghadapi realitas atau kenyataan yang ada. Pendekatan ini juga tidak memberi perhatian-perhatian pada motif-motif bawah sadar seperti psikoanalisis. Inti terapi realitas adalah penerimaan tanggung jawab pribadi yang dipersamakan dengan kesehatan mental.

\section{METODE}

Bagian Penelitian ini menggunakan pendekatan kuantitatif dengan metode penelitian eksperimen. Jenis penelitian yang dilakukan dalam penelitian ini adalah eksperimen semu (quasi experimental) dengan desain One Group Pretest-Posttest Design.

Adapun design penelitian ini adalah sebagai berikut:

\section{$\mathrm{O} 1 \times \mathrm{O} 2$}

Keterangan:

O1: Skor Pretest (Sebelum diberi perlakuan)
$\times$ :
Perlakuan
(Pemberian

layanan KKP pendekatan realitas)

O2: Skor Posttest (Sesudah diberi perlakuan)

Sample dalam penelitian ini sebanyak 8 orang siswa yang memiliki kemandirian belajar rendah. Pengumpulan data dalam penelitian ini dilakukan dengan menggunakan skala kemandirian belajar yang dibagikan kepada siswa. Alasan penggunaan uji Wilcoxon adalah karena sampel peneliti berukuran kecil. Uji Wilcoxon yaitu uji satu pihak "test rangking bertanda wilcoxon"yang dikemukakan oleh Siegel Jr (dalam Sudjana, 2005:450). 


\section{HASIL DAN PEMBAHASAN}

Berdasarkan hasil analisis ini, bahwa hipotesis penelitian diterima, artinya terdapat Pengaruh Layanan Konseling Kelompok Pendekatan Realitas Terhadap Kemandirian Belajar Pada Siswa Kelas VII di MTs Negeri 2 Medan T.A 2018/2019. Hal ini telah ditunjukkan dari hasil perhitungan uji wilcoxon yaitu nilai Jhitung $=16$ dengan $\alpha=0,05$ dan $\mathrm{n}=8$, sehingga nilai Jtabel adalah 4. Dari data tersebut terlihat bahwa Jhitung $>$ Jtabel dimana $16>4$.

Perubahan signifikan kemandirian belajar yang dialami siswa tersebut membuktikan bahwa konseling kelompok pendekatan realitas dapat digunakan untuk menyelesaikan permasalahan belajar siswa dalam hal ini fokus penelitian adalah masalah kurangnya kemandirian belajar siswa. Hal ini sesuai dengan pendapat Gerald Corey (2013:280) yang menyatakan terapi realitas memiliki implikasi-implikasi langsung bagi situasi-situasi sekolah. Glasser untuk pertama kali menaruh perhatian pada masalah-masalah belajar dan tingkah laku anak-anak dimana dalam terapi ini membantu para siswa dalam mengembangkan tingkah laku yang bertanggung jawab. Mengingat pentingnya kemandirian belajar dalam proses pencapaian hasil belajar siswa, maka untuk membantu meningkatkan kemandirian belajar siswa perlu kesadaran dan membangun komitmen dalam diri siswa untuk lebih bertanggungjawab dalam belajar hal ini bertujuan agar siswa memahami tugas-tugas sebagai pelajar dan mempersiapkan diri untuk menggapai citacita dimasa depan dan selalu memiliki kemandirian yang tinggi dalam belajar.

Hal tersebut dapat dilakukan melalui pemberian layanan konseling kelompok pendekatan realitas. Konseling realitas merupakan suatu bentuk hubungan pertolongan yang praktis, relatif sederhana, dan bentuk bantuan langsung kepada konseli, yang dapat dilakukan konselor disekolah dalam rangka mengembangkan dan membina kepribadian kesehatan mental konseli secara sukses, dengan cara memberi tanggung jawab kepada konseli yang bersangkutan.

Konseling kelompok pendekatan realitas merupakan salah suatu upaya dalam mengatasi kemandirian belajar siswa yang rendah di MTsN 2 Medan. Konseling Kelompok Pendekatan Realitas adalah bentuk konseling yang difokuskan pada tingkah laku sekarang, bentuk bantuan langsung kepada konseli secara kelompok, yang dilakukan oleh konselor dengan cara memberi tanggung jawab kepada konseli yang didasarkan pada keyakinan bahwa kita semua memilih apa yang kita lakukan dengan hidup kita dan kita bertanggung jawab untuk pilihan kita. Hal ini sejalan dengan Kurnanto (2014:81) yang menyatakan bahwa tujuan dari pendekatan realitas ini adalah menolong individu agar mampu mengurus diri sendiri, supaya dapat menentuan dan melaksanakan perilaku dalam bentuk nyata, mendorong konseli agar berani bertanggung jawab serta memikul segala risiko yang ada sesuai dengan kemampuan dan dalam perkembangan dan pertumbuhannya, mengembangkan rencana-rencana nyata dan realistik dalam mencapai tujuan yang telah ditetapkan, intinya pendekatan ini ditekankan pada disiplin dan tanggung jawab atas kesadaran sendiri.

Secara umum semua konseli mengalami peningkatan skor kemandirian belajar. Salah satunya kemungkinan 
mengapa ini terjadi karena faktor siswa itu sendiri (internal) yaitu kecenderungan minat yang tinggi untuk berubah dan mengendalikan diri dalam usahanya untuk mencapai kebutuhan dasar secara bertanggung jawab dan realistis. Hasil penelitian ini memperkuat penelitian terdahulu dari Glasser (2010) dimana ia melaporkan bahwa satu-satunya orang yang bisa anda kendalikan untuk mencapai kebutuhan dasar menurut terapi realitas adalah diri anda sendiri. Ini berarti bahwa individu sangat menentukan dalam hubungannya pencapaian kebutuhan dasar secara realistis dan bertanggung jawab.

Penelitian lain yang mendukung penelitian ini adalah penelitian Bernardus Widodo (2010) “Keefektifan Konseling Kelompok Realitas Mengatasi Persoalan Perilaku Disiplin Siswa di Sekolah", menyimpulkan bahwa penggunaan pendekatan konseling kelompok realitas efektif untuk mengatasi persoalan perilaku disiplin siswa di sekolah, yang ditandai dengan meningkatnya aspek pengendalian diri (yaitu aspek kontrol perilaku, kontrol kognitif dan kontrol keputusan) siswa dan menurunnya perilaku tidak disiplin pada siswa di sekolah sesudah mendapat perlakuan konseling kelompok realitas dapat diterima.

Dalam hal ini peneliti membantu siswa dalam menemukan alternatif-altenatif dalam mencapai tujuan konseling kelompok yang ingin dicapai yaitu tujuan siswa sendiri untuk dapat meningkatkan kemandirian belajarnya. Dalam penelitian ini, konseling kelompok pendekatan realitas membantu siswa mencapai tingkah laku bertanggung jawab dan komitmen terutama dengan tugas akademik. Siswa dapat mengikuti komitmen-komitmennya sendiri sehingga mampu mengatasi masalah rendahnya kemandirian dalam belajar yang masih tinggi. Dalam perkembangannya, siswa lebih bertanggung jawab atas dirinya sendiri dan realistis dalam melakukan suatu tindakan atau kegiatan, mampu menilai perilakunya sendiri dan menyusun rencana-rencana yang tepat untuk tujuannya sendiri.

Berdasarkan analisis secara keseluruhan dari 8 orang responden, diperoleh skor total pre-test (sebelum diberi perlakuan) sebesar 680, dan skor total post-test (setelah diberi perlakuan) diperoleh sebesar 1031, dengan selisih skor total kemandirian belajar yaitu sebesar 351, maka terjadi peningkatan kemandirian belajar sebesar 51,61\%. Adapun skor tertinggi pre-test (sebelum diberi perlakuan) diperoleh sebesar 92, dan skor tertinggi post-test (setelah diberi perlakuan) diperoleh sebesar 146, dengan selisih skor kemandirian belajar tertinggi yaitu sebesar 56, maka terjadi peningkatan kemandirian belajar sebesar 66,66\%. Sedangkan skor terendah pre-test (sebelum diberikan perlakuan) diperoleh sebesar 73, dan skor terendah post-test (setelah diberi perlakuan) diperoleh sebesar 103, dengan selisih skor kemandirian belajar terendah yaitu sebesar 29, maka terjadi peningkatan kemandirian belajar sebesar 31,52\%. Dengan demikian maka diperoleh skor rata-rata pre-test (sebelum diberi perlakuan) yaitu sebesar 85 dan skor ratarata post-test (setelah diberi perlakuan) sebesar 128,87, dengan selisih skor rata-rata kemandirian belajar yaitu sebesar 43,87, maka terjadi peningkatan kemandirian belajar sebesar 51,61\%, artinya rata-rata skor kemandirian belajar lebih rendah sebelum mendapatkan layanan konseling kelompok pendekatan realitas, dan setelah diberikan layanan konseling kelompok pendekatan realitas maka kemandirian belajar siswa menjadi meningkat. 
Namun demikian jika ditinjau secara individual, masih ditemukan responden yang memiliki perubahan rendah/kecil yaitu MZ, dimana ia mendapatkan skor pre-test (sebelum diberi perlakuan) sebesar 92 dengan kategori rendah dan skor posttest (setelah diberi perlakuan) sebesar 121 dengan kategori sedang. Maka MZ mengalami selisih skor kemandirian belajar sebesar 29, artinya MZ mendapatkan peningkatan kemandirian belajar sebesar $31,52 \%$, dapat dilihat bahwa perubahan skor sebelum dan sesudah mendapatkan layanan konseling kelompok pendekatan realitas hanya sedikit terjadi peningkatan. Perubahan kecil yang dialami oleh MZ ini disebabkan oleh karena MZ kurang serius dan tidak konsentrasi selama mengikuti layanan konseling kelompok pendekatan realitas, ia terlihat ragu bisa mengubah perilaku yang tidak bertanggung jawab menjadi bertanggung jawab. MZ tidak terlihat antusias atau tidak semangat selama beberapa pertemuan, MZ selalu mengatakan bahwa bosan ketika pelajaran dimulai, ia juga mengatakan kurang bisa mengontrol dirinya untuk tidak ribut di kelas, terlihat bahwa $\mathrm{MZ}$ pesimis untuk kemajuan dalam dirinya, sehingga perubahan yang ia alami termasuk kecil hal ini dapat diterima berdasarkan penelitian Saragih, Putri \& Asmah (2018) menyatakan bahwa hasil bimbingan kelompok dapat di pengaruhi oleh gender.

Dapat dilihat bahwa perubahan yang dilakukan individu tersebut, karena diri mereka sendiri, peneliti hanya sebagai fasilitator, individu itu sendirilah yang memilih dirinya, untuk dirinya dan dia sendiri juga yang memilih bagaimana caranya untuk mencapai kebutuhan dasar secara sehat, tanpa harus melanggar aturan atau norma hukum yang berlaku (right), bertanggung jawab dan realistis.
Ketika melaksanakan rangkaian penelitian ini, peneliti menemukan beberapa kesulitan yang dihadapi seperti waktu kegiatan pelaksanaan konseling kelompok bertabrakan dengan mata pelajaran bidang studi, namun kesulitan ini dapat teratasi dengan meminta kesepakatan dengan guru bidang studi dan dengan bantuan guru BK MTs Negeri 2 Medan sehingga penelitian ini berjalan dengan baik dan lancar.

\section{SIMPULAN}

Berdasarkan hasil penelitian ditunjukan dengan analisis data dan pembahasan maka peneliti dapat menyimpulkan bahwa Terdapat Pengaruh Layanan Konseling Kelompok Pendekatan Realitas Terhadap Kemandirian Belajar Siswa Kelas VII MTsN 2 Medan Tahun Ajaran 2018/2019, artinya hipotesis diterima. Hal ini dapat dilihat dari hasil analisis data dalam penelitian ini, yaitu Jhitung = 16, dengan $\alpha=0,05$ dan $\mathrm{n}=8$, maka berdasarkan daftar, Jtabel $=4$. Dari data tersebut terlihat bahwa Jhitung > JTabel dimana $16>4$, artinya hipotesis diterima. Data yang dapat memperkuat adanya peningkatan skor kemandirian belajar adalah dengan melihat skor pre-test diperoleh rata-rata 85, sedangkan data post-test setelah diberikan perlakuan konseling kelompok pendekatan realitas diperoleh rata-rata sebesar 128,87 . Artinya skor rata-rata siswa setelah mendapat layanan konseling kelompok pendekatan realitas lebih tinggi daripada sebelum mendapat layanan konseling kelompok pendekatan realitas. Perubahan peningkatan interval kemandirian belajar setelah diberi layanan konseling kelompok pendekatan realitas sebesar $51,61 \%$. Hal ini menunjukkan adanya pengaruh layanan konseling kelompok pendekatan realitas 
terhadap kemandirian belajar siswa kelas VII-9 di MTsN 2 Medan T.A 2018/2019.

Adapun keunggulan konseling kelompok realitas sehingga dapat meningkatkan kemandirian belajar siswa yaitu, layanan ini lebih menekankan pada kekuatan pribadi, dan pada dasarnya merupakan jalan dimana konseli dapat belajar secara realistik dalam mencapai keberhasilan. Semua perilaku itu digerakan dari dalam diri individu sendiri dan masing-masing pribadi memiliki pilihan kepada apa yang akan dilakukan konseling realita lebih menekankan kontrol diri individu itu sendiri agar mampu mengontrol dirinya, mengotrol perilakunya yang kurang pantas, dan menuju perilaku yang bertanggung jawab. Dengan adanya pengaruh tersebut, maka layanan konseling kelompok pendekatan realitas merupakan salah satu metode dalam BK yang mampu mengatasi kemandirian belajar siswa yang rendah.

\section{DAFTAR PUSTAKA}

Basri, Hasan. (1996.) Remaja Berkualitas. Yogyakarta: Pustaka Pelajar.

Corey, Gerald. (2013). Teori dan Praktek Konseling dan Psikoterapi. Bandung: Refika Aditama

Fatimah, Enung. (2006). Psikologi Perkembangan (Perkembangan Peserta Didik). Bandung: Pustaka Setia.

Kurnanto, Edi. (2014). Konseling Kelompok. Bandung: Alfabeta.

Rusman. (2017).

Model-Model

Pembelajaran: Mengembangkan

Profesionalisme Guru. Jakarta: Rajawali Pers.

Sudjana. (2005). Metode Statistika Edisi ke6. Bandung: Tarsito.
Yamin, Martinis. (2017). Paradigma Baru Pembelajaran. Jakarta:

Gaung Persada.Winkel, W. S., \& Hastuti, M. S. (2005). Bimbingan dan Konseling di Institusi Pendidikan. Media Abadi.

Saragih, N. A., Putri, E., \& Asmah, N. (2018). Pengaruh Gender Terhadap Interaksi Sosial Dalam Pelaksanaan Layanan Bimbingan Kelompok Siswa SMP. ENLIGHTEN: Jurnal Bimbingan Konseling Islam, 1(1), 21-31. https://doi.org/10.32505/enlighten.v1i1. 512 